\title{
Effect of different concentrations of saffron corm and leaf residue on the early growth of arugula, chickpea and fenugreek under greenhouse conditions
}

\author{
Hamid-Reza FALLAHI $^{1 *}$, Mahsa AGHHAVANI-SHAJARI ${ }^{2}$, Ferdinando BRANCA $^{3}$, Javad DAVARZANI ${ }^{4}$
}

Received April 16, 2017; accepted March 20, 2018.

Delo je prispelo 16. aprila 2017, sprejeto 20. marca 2018.

\begin{abstract}
In this study the effect of different concentrations of leaf (LR) and corm residue (CR) of saffron on seedling growth of fenugreek (Trigonella foenum-graecum L.), chickpea (Cicer arietinum L.) and arugula (Eruca sativa Mill.) as three potential companion crops for saffron were investigated under greenhouse condition. The experimental treatments were four concentrations $(0.5,1.5,3$ and $6 \%)$ together with no residue treatment of LR and CR were arranged in completely randomized design. Results showed that the highest emergence percentage of chickpea was obtained at LR concentration of $6 \%$. Chickpea shoot length and mass had an increasing trend with increase in concentrations of saffron CR. LR and CR of saffron only at concentration of 3 and $6 \%$ reduced the emergence percentage and emergence rate of fenugreek, but all concentration of CR and LR had no negative effect on length and mass of shoot. Saffron residue imposed a slight inhibitory effect on emergence percent and emergence rate of arugula, while had it a positive effect on some seedling growth characters especially root dry mass. Hence, three tested crops can be recommended as potential candidates to be associated with the saffron, although, the growth response of selected plants was dose-dependent and somewhat different.
\end{abstract}

Key words: saffron residue; associated crop; germination; seedling growth
IZVLEČEK

\section{UČINKI RAZLIČNIH KONCENTRACIJ OSTANKOV GOMOLJEV IN LISTOV ŽAFRANA NA ZGODNJO RAST RUKVICE, ČIČERKE IN SABLJASTEGA TRIPLATA V RASTLINJAKU}

$\mathrm{V}$ raziskavi so bili preučevani učinki različnih koncentracij ostankov listov (LR) in čebulastih gomoljev (CR) žafrana na rast sejank sabljastega triplata (Trigonella foenum-graecum L.), čičerke (Cicer arietinum L.) in rukvice (Eruca sativa Mill.) kot treh potencialnih soposevkov žafrana $\mathrm{v}$ rastlinjaku. Poskusna obravnavanja so obsegala štiri koncentracije $(0.5,1.5,3$ in $6 \%)$ ostankov listov in gomoljev žafrana in kontrolo brez teh dodatkov $\mathrm{v}$ popolnem naključnem poskusu. Rezultati so pokazali, da je bil največji vznik čičerke pri uporabi listnih ostankov žafrana $\mathrm{v}$ koncentraciji $6 \%$. Masa in dolžina pogankov čičerke sta se povečevali $\mathrm{z}$ naraščajočo koncentracijo ostankov gomoljev žafrana. Dodatek ostankov listov in gomoljev žafrana $v$ koncentracijah med 3 in $6 \%$ je zmanjšal odstotek vznika sabljastega triplata, vendar so imeli dodatli listnih in gomoljevih ostankov žafrana negativni učinek na dolžino in maso poganjkov te rastline. Ostanki žafrana so imeli rahel zaviralni učinek na vznik rukvice, a so imeli pozitivni učinek na nekatere rastne parameter te vrste, še posebej na suho maso korenin. Zaključimo lahko, da bi te polščine lahko priporočili kot potencialne kandidate za vmesne posevke $\mathrm{v}$ žafranu, čeprav je njihov rastnih odziv nekoliko različen in odvisen od koncentracije ostankov žafrana.

Ključne besede: ostanki žafrana; soposevki; kalitev; rast sejank

\section{INTRODUCTION}

Saffron (Crocus sativus L.) as the most expensive spice of the world is used in the food, dairy, dye, cosmetic and perfume industries and also has cooking and medical applications (Molina et al., 2005; Kumar et al., 2009). This plant perhaps originated from Iran, Greece and Asia Minor with a long history of cultivation in Iran and currently being cultivated in Iran, Spain, India, Egypt, Turkey, Pakistan, Azerbaijan, Greece, France, Italy, Morocco, China, and some other countries around the world (Kumar et al., 2009). Iran with about 336 tons

1 Assistant Professor in Crop Ecology, Saffron Research Group, Department of Agronomy and Plant Breeding, Faculty of Agriculture, University of Birjand, Birjand, Iran;*Corresponding author: Hamidreza.Fallahi@birjand.ac.ir

2 Ph.D. in Agroecology, Department of Agronomy, Faculty of Agriculture, Ferdowsi University of Mashhad, Mashhad, Iran

3 Associate Professor, Department of Agriculture, University of Catania, Catania, Italy

4 MSc graduated in Agronomy and Plant Breeding, Sarayan Faculty of Agriculture, University of Birjand, Birjand, Iran 
dry stigma production per year is currently the world's largest producer and exporter of saffron so that, about $90 \%$ of the global production of this valuable crop is belonged to Iran. Khorasan-Razavi and Southern Khorasan provinces, respectively, with 82700 and 14450 ha area under cultivation and annual production of 258 and 51 tons, have a significant share of saffron global production (Mohammad-Abadi et al., 2011; Koocheki et al., 2016). Due to the special canopy structure of saffron, some of the light and the space are not used appropriately. Furthermore, it's non-extensive and partially shallow root system causes that water and nutrient to be absorbed only from the topsoil. Therefore, the use of suitable intercropping systems can be a useful method for efficient use of these above and underground resources (Koocheki et al., 2016; Fallahi et al., 2014).So far, very few studies have been conducted on the feasibility of intercropping of saffron with catch and cover crops. In a study Khosravi (2005) reported that the use of saffron-black cumin (Bunium persicum (Boiss.) B. Fedtsch. Syn.. Carum persicum Boiss.) intercropping is a suitable way for filling the empty spaces, weeds control and increasing inputs use efficiencies. Also, results of Faravani et al. (2010) in an intercropping system of saffron with black cumin (black zira or black caraway) revealed that the maximum stigma yield of saffron and seed yield of black cumin were obtained in planting ratio of 67:33 for saffron and black cumin, respectively. Results of Koocheki et al. (2009) showed that application of some spring crops such as chickpea (Cicer arietinum L.), ajowan (Carum copticum (L.) Link.)) and green cumin (Cuminum cyminum L.) can be considered as a component crop in saffron cultivation. In another study it has been reported that the use of Persian clover (Trifolium resupinatum $\mathrm{L}$.) and fodder pea (Lathyrus annus L.) as associated crops with saffron is an effective way for improving of growth and yield of saffron (Koocheki et al., 2016). NaderiDarbaghshahi et al. (2012) also found that saffron intercropping with three species of daisy family, Asteraceae, (Matricaria chamomilla L., Tanacetum parthenium (L.) Sch. Bip. and Anthemis nobilis L.) is possible, without any competition between main crop and associated crops. Koocheki et al. (2009) focused on the cultivation of associated crops that a part of their life cycle was simultaneous with saffron dormancy period. They concluded that there was a negative relationship between the growth period length and irrigation times of associated crops with saffron yield. Therefore, it seems that application of winter associated crops with maximum matching to vegetative phase of saffron growth is a more appropriate strategy (Koocheki et al., 2016).

Saffron is a summer dormant and winter active, low water requirement and low input crop with partially shallow root system which has also allelopathic effects on some other crops (Eghbali et al., 2008; RashedMohassel et al., 2009; Koocheki et al., 2009; Kumar et al., 2009). Therefore, it seems that the selected associated crops for use in saffron intercropping systems must have certain characteristics including: 1 maximum coincidence between the growth of selected crop with saffron vegetative growth stage (NaderiDarbaghshahi et al., 2012), 2 - shorter growth cycle for reducing the irrigation times of spring associated crop and consequently avoidance from the loss of saffron yield (Koocheki et al., 2009), 3 - the different root system compared with saffron, 4 - low nutritional demand, 5 - producing sufficient organic matter that would be incorporated into the soil, 6 - the ability for nitrogen fixation or improving soil aggregation, 7 producing residue with high decomposability and suitable C:N ratio (Koocheki et al., 2016), 8 - resistance to cold for winter associated crops, 9 - low water demand and resistance to drought stress regarding the low water requirement of saffron and its distribution in dry regains of Iran (Eghbali et al., 2008; Koocheki et al., 2009) and 10 - the lack of strong negative allelopathic effects between saffron and associated crop, because the intercropping is possible if there is no allelopathic effect between intercropped crops (Abbasi \& Jahani, 2007; Fallahi et al., 2014). Accordingly, in this research three associated crops were selected and as the first step the possible inhibitory effects of saffron on these plants was explored.

Allelopathy is defined as the inhibitory or stimulatory biochemical interactions within plants using secondary metabolites (allelochemicals) especially phenolic acids and the terpenoid compounds (Chengxu et al., 2011; ElDarier \& El-Dien, 2011). In some studies the inhibiting or sometimes stimulating effects of saffron petal, leaf and corm residue on germination and seedling growth criteria of some crops including redroot pigweed (Amaranthus retroflexus L.), lambs quarter (Chenopodium album L.), common vetch (Vicia sativa L.), common bean (Phaseolus vulgaris L.), soybean (Glycine $\max$ (L.) Merr.), common wheat (Triticum aestivum L.), rye (Secale cereale L.), common barley (Hordeum vulgare L.), corn (Zea mays L.), canola (Brassica napus L. ssp. napus), Mexican cotton (Gossypium hirsutum L.), alfalfa (Medicago sativa L.), and arugula (Eruca sativa Mill.) has been reported (Eskandari- Torbaghan et al., 2007; Abbasi \& Jahani, 2007; Eghbali et al., 2008; Rashed-Mohassel et al., 2009; Fallahi et al., 2014).

Investigations on the feasibility of saffron intercropping with other crops that can provide the more favorable growth condition for main crop and also increase the farmer income, has high importance. In this regards the first step is to ensure from the absence of strong inhibitory effects between the saffron and selected 
associated crops. It must be also noted that the chemical composition of saffron leaves and corms are some different. For example, the corms have essential amino acids, glucose, glutamic acid, glycine, alanine, lysine, histidine, proline, leucine and secondary metabolites such as anthraquinones, while phenolic and flavonoid compounds has been identified in leaves (Behdani \& Fallahi, 2015). Accordingly, the allelopathic effects of leaves and corms may be different, as well as the response of received crop of allelochemicals may also be dose dependent. Therefore, the aim of this study was to find out the possible allelopathic effects of different concentrations of saffron corms and leaves residue on early growth of fenugreek, chickpea and arugula. We chose these crops due partially to their growth cycle, relatively low competitiveness, low nutrient demand, the ability to biologically fix atmospheric nitrogen and possible crop establishment in autumn.

\section{MATERIALS AND METHODS}

In order to investigate the effect of saffron (land race of Sarayan) leaf (LR) and corm (CR) residue on seedling growth of fenugreek, chickpea and arugula three separate experiments were conducted based on a completely randomized design with three replications (a one-way ANOVA analysis) in the greenhouse of Sarayan Faculty of Agriculture, University of Birjand in 2014. In the first experiment the effects of four concentrations of $\operatorname{LR}(0.5,1.5,3$ and $6 \%)$ and four concentrations of CR $(0.5,1.5,3$ and $6 \%)$ along with the control treatment (no-residue application) was evaluated on emergence and initial growth indices of chickpea. Similarly, in the second and the third experiments the effects of mentioned CR and LR levels were studied on emergence and seedling growth of fenugreek and arugula, respectively. The concentrations were selected based on previous studies that have been conducted about allelopathic effects of saffron on similar plants such as canola (Brassicaceae), soybean, vetch and bean (Leguminosae) (Abbasi \& Jahani, 2007; Eghbali et al., 2008). These crops were they of the same botanical groupings as the test crop used in this experiment (fenugreek and chickpea from Leguminosae and arugula from Brassicaceae) to have justified the choice of concentration used.

The leaves and corms of saffron were harvested and dried separately at $75{ }^{\circ} \mathrm{C}$ for 72 hours and then were milled. After that, appropriate values of milled leaf and corm residue were mixed separately with soil $(0$ as control treatment as well as $5,15,30$ and $60 \mathrm{~g} \mathrm{~kg}^{-1}$ soil for concentrations of $0,0.5,1.5,3$ and $6 \%$, respectively) and then mixed samples were poured into the cotton bags and were kept in greenhouse for 35 days (Eghbali et al., 2008). The aim of this period of time was to ensure the decomposition of plant residue (ambient temperature was $20-25^{\circ} \mathrm{C}$ ). During this period, the moisture of samples was adjusted about in field capacity (FC) point (by weighing two days among the samples and adding water lost) for appropriate decomposition and also avoiding of saffron residue leaching from the soil (Eghbali et al., 2008). Finally, the prepared soil samples were used in planting trays for conducting the experiments. For each treatment, one row of planting trays (including 7 planting hole) was considered as an experimental unit (one replication) and then in each planting hole 5, 2 and 3 seeds were planted for arugula, chickpea and fenugreek (all landrace), respectively (35, 14 and 21 seeds in each experimental unit for mentioned plants, respectively). The difference in planted seed number between tested crops was due to difference in their canopy and root system size as well as differences in their dormancy and viability. All emerged plants were used at the end of experiment for destructive sampling. Soil mass in each experimental unit was about $100 \mathrm{~g}$ and the planting depth was 1-1.5 $\mathrm{cm}$. The greenhouse temperature for germination of arugula, chickpea and fenugreek was kept at 17 (Jalilian \& Khalili Aqdam, 2014), 26 (Ganjeali et al., 2011) and $21{ }^{\circ} \mathrm{C}$ (Mehrafarin et al., 2011b), which are the optimum temperatures for them, respectively.

After sowing, the irrigation of planting trays was done daily with distillated water. The amount of used water was so low that it would be avoided from leaching of plant residues used in the soil $(\sim 60 \mathrm{ml}$ for each experimental unit). The emerged seedlings were counted daily in the morning for ten days. At the end of tenth day, in each treatment the seedlings were removed from the soil and after washing, the shoot and seminal root lengths were determined. After that, all emerged seedlings in each treatment, were dried at $75{ }^{\circ} \mathrm{C}$ for 48 hours and then the average mass of seminal root and shoot were measured. Moreover, emergence rate (equivalent to germination rate in Petri Dish studies) was calculated using the below formula which has been developed by Maguire (1962).

$$
R s=\sum_{i=1}^{n} \frac{S_{i}}{D_{i}}
$$

In which $\mathrm{Rs}$ is emergence rate, $\mathrm{Si}$ is daily seed emergence, Di is number of day to $\mathrm{n}$ computation and $\mathrm{n}$ is number of days computation. 
Finally, for each of the variate, normality test (Kolmogorov-Smirnov) was done (Marsaglia et al., 2003) and data transformation (Arc-sin) was applied about emergence percent. Then, data analysis was carried out using ANOVA one-way analysis and calculations were done with SAS 9.1. In addition, means were compared by the Duncan's multiple ranges test at the $5 \%$ level of probability.

\section{RESULTS AND DISCUSSION}

\subsection{Effect of saffron residue on chickpea early growth}

Saffron leaf and corm residue had significant effect on all the growth variables except root length (Table 1). There was no significant difference between leaf residue concentrations in terms of emergence percentage and emergence rate. Low levels of saffron corm residue (up to $1.5 \%$ ) imposed an increasing effect on emergence percentage and emergence rate, while higher levels of corm residue had a decreasing effect on these indices. However, it should be noted that emergence percentage of chickpea at $6 \%$ concentration of corm residue was $12 \%$ more than its $3 \%$ concentration (Table 2). Allelochemicals have a threshold concentration which their effects below or over it can be different depending upon the sensitivity of the receiving species (Chon \& Nelson, 2010). Considering appropriate growth of chickpea even at the highest corm residue concentration, it seems that the corm concentrations of more than $6 \%$ is a threshold point for chickpea as receiving species. Plant growth can be increased below the allelopathic threshold, but severe growth reductions occur above the threshold concentration (Chon \& Nelson, 2010).

There was statistically no significant different between control and all levels of leaf residue in terms of seminal root and shoot length. The effect of corm residue on shoot length was different from what was observed about leaf residue, so that, this index increased considerably in all levels of corm residues. For example, the value of shoot length at $6 \%$ corm residue concentration was 2.31 times more than control (5.33 vs. $12.33 \mathrm{~cm}$ ) (Table 2). Root dry mass of chickpea at leaf and corm concentration of $0.5 \%$ had no significant difference with the control treatment, but more increase in residue concentration reduced this index. Increasing concentration of corm residue significantly increased shoot dry mass, while there was no significant difference between leaves residue levels with the control treatment in terms of shoot mass. In addition, all levels of corm residue decreased the root to shoot ratio in terms of length and mass compared with the control treatment (Table 2). In this regard, Farooq et al. (2013) reported that allelochemicals promote plant growth at certain concentration, which may be a reason for our findings, if we assume that the exudates from the saffron residues have allelopathic effect. They stated that allelochemicals secreted into rhizosphere improved nutrients availability through the processes of solubility, biological nitrification inhibition, chelation and selected retention. Understanding the possible reason of our observation required more research on precise identification of chemical compounds exudates by saffron residues into soil.

Table 1: Mean of square for the effects of experimental treatments (different concentrations of saffron corm and leaf residue) on emergence and seedling growth criteria of chickpea

\begin{tabular}{|c|c|c|c|c|c|c|c|c|c|}
\hline $\begin{array}{l}\text { Sources of } \\
\text { variation }\end{array}$ & $\mathrm{df}$ & $\begin{array}{l}\text { Emergence } \\
\text { percentage }\end{array}$ & $\begin{array}{c}\text { Emergence } \\
\text { rate }\end{array}$ & $\begin{array}{l}\text { Root } \\
\text { length }\end{array}$ & $\begin{array}{l}\text { Shoot } \\
\text { length }\end{array}$ & $\begin{array}{l}\text { Root to } \\
\text { shoot } \\
\text { length } \\
\text { ratio }\end{array}$ & $\begin{array}{c}\text { Root dry } \\
\text { mass }\end{array}$ & $\begin{array}{l}\text { Shoot dry } \\
\text { mass }\end{array}$ & $\begin{array}{l}\text { Root to } \\
\text { shoot } \\
\text { mass } \\
\text { ratio }\end{array}$ \\
\hline Treatment & 8 & $323.1^{*}$ & $1.01^{* * *}$ & $3.56^{\mathrm{ns}}$ & $26.34^{* *}$ & $0.49^{* * *}$ & $0.00017^{* *}$ & $0.00019^{* * *}$ & $1.23^{* * *}$ \\
\hline Error & 18 & 122.7 & 0.11 & 2.27 & 3.02 & 0.11 & 0.00004 & 0.00001 & 0.099 \\
\hline C.V & - & 12.3 & 14.3 & 11.54 & 12.49 & 11.95 & 19.24 & 14.56 & 13.61 \\
\hline
\end{tabular}

$* *, *$ and ns, significant in $1 \%$ and $5 \%$ levels and not significant, respectively.

df and CV are degree of freedom and coefficient of variation, respectively. 
Effect of different concentrations of saffron ... of arugula, chickpea and fenugreek under greenhouse conditions

Table 2: Mean comparisons of the effects of different levels of saffron corm and leaf residue on emergence and seedling growth criteria of chickpea

\begin{tabular}{lcccccccc}
\hline $\begin{array}{c}\text { Treatment } \\
\text { percentage of } \\
\text { residue) }\end{array}$ & $\begin{array}{c}\text { Emergence } \\
\text { percentage }\end{array}$ & $\begin{array}{c}\text { Emergence } \\
\text { rate } \\
\text { (seedling } \\
\text { per day) }\end{array}$ & $\begin{array}{c}\text { Root } \\
\text { length } \\
(\mathrm{cm})\end{array}$ & $\begin{array}{c}\text { Shoot } \\
\text { length } \\
(\mathrm{cm})\end{array}$ & $\begin{array}{c}\text { Root to } \\
\text { shoot } \\
\text { length } \\
\text { ratio }\end{array}$ & $\begin{array}{c}\text { Root dry } \\
\text { mass (g) }\end{array}$ & $\begin{array}{c}\text { Shoot } \\
\text { dry } \\
\text { mass (g) }\end{array}$ & $\begin{array}{c}\text { Root to } \\
\text { shoot } \\
\text { mass } \\
\text { ratio }\end{array}$ \\
\hline Control $(0.0 \%)$ & $95.3^{\mathrm{a}}$ & $2.47^{\mathrm{b}}$ & $7.63^{\mathrm{ab}}$ & $5.33^{\mathrm{c}}$ & $1.46^{\mathrm{ab}}$ & $0.038^{\mathrm{ab}}$ & $0.016^{\mathrm{cd}}$ & $2.31^{\mathrm{a}}$ \\
$\mathrm{L}^{*} 0.5 \%$ & $90.6^{\mathrm{a}}$ & $2.24^{\mathrm{bc}}$ & $5.96^{\mathrm{ab}}$ & $5.33^{\mathrm{c}}$ & $1.23^{\mathrm{a}-\mathrm{d}}$ & $0.049^{\mathrm{a}}$ & $0.019^{\mathrm{cd}}$ & $2.60^{\mathrm{a}}$ \\
$\mathrm{L} 1.5 \%$ & $80.6^{\mathrm{ab}}$ & $1.75^{\mathrm{cd}}$ & $7.53^{\mathrm{ab}}$ & $4.33^{\mathrm{c}}$ & $1.73^{\mathrm{a}}$ & $0.028^{\mathrm{bc}}$ & $0.014^{\mathrm{d}}$ & $2.04^{\mathrm{a}}$ \\
$\mathrm{L} 3.0 \%$ & $97.6^{\mathrm{a}}$ & $2.34^{\mathrm{bc}}$ & $7.00^{\mathrm{ab}}$ & $5.16^{\mathrm{c}}$ & $1.40^{\mathrm{abc}}$ & $0.038^{\mathrm{ab}}$ & $0.015^{\mathrm{d}}$ & $2.50^{\mathrm{a}}$ \\
$\mathrm{L} 6.0 \%$ & $100.0^{\mathrm{a}}$ & $2.75^{\mathrm{b}}$ & $5.36^{\mathrm{b}}$ & $6.46^{\mathrm{bc}}$ & $0.86^{\mathrm{bcd}}$ & $0.029^{\mathrm{bc}}$ & $0.014^{\mathrm{d}}$ & $2.01^{\mathrm{a}}$ \\
$\mathrm{C} 0.5 \%$ & $93.0^{\mathrm{a}}$ & $3.46^{\mathrm{a}}$ & $7.56^{\mathrm{ab}}$ & $10.10^{\mathrm{a}}$ & $0.766^{\mathrm{cd}}$ & $0.040^{\mathrm{ab}}$ & $0.028^{\mathrm{b}}$ & $1.41^{\mathrm{b}}$ \\
$\mathrm{C} 1.5 \%$ & $97.6^{\mathrm{a}}$ & $2.51^{\mathrm{b}}$ & $8.56^{\mathrm{a}}$ & $11.03^{\mathrm{a}}$ & $0.780^{\mathrm{cd}}$ & $0.032^{\mathrm{bc}}$ & $0.029^{\mathrm{b}}$ & $1.07^{\mathrm{b}}$ \\
$\mathrm{C} 3.0 \%$ & $69.0^{\mathrm{b}}$ & $1.41^{\mathrm{d}}$ & $5.66^{\mathrm{ab}}$ & $9.23^{\mathrm{ab}}$ & $0.610^{\mathrm{d}}$ & $0.024^{\mathrm{c}}$ & $0.022^{\mathrm{c}}$ & $1.09^{\mathrm{b}}$ \\
$\mathrm{C} 6.0 \%$ & $81.0^{\mathrm{ab}}$ & $2.28^{\mathrm{bc}}$ & $7.73^{\mathrm{ab}}$ & $12.33^{\mathrm{a}}$ & $0.666^{\mathrm{d}}$ & $0.037^{\mathrm{ab}}$ & $0.037^{\mathrm{a}}$ & $1.02^{\mathrm{b}}$ \\
\hline
\end{tabular}

$* \mathrm{~L}=$ leaf residue and $\mathrm{C}=$ corm residue. Means with the same letters in each column are not significantly different at the 0.05 level of probability.

On average there was no considerable difference between leaf and corm residue of saffron in terms of emergence percentage and emergence rate of chickpea. Mean data obtained from all levels of saffron residue revealed that emergence percent of chickpea for leaf and corm residue were $92.2 \%$ and $85.2 \%$, and emergence rate were 2.27 and 2.42 seedling per day, respectively. In addition, mean root length in all corm residue treatments was $7.38 \mathrm{~cm}$ and in leaf residue was $6.46 \mathrm{~cm}$. This difference was higher for shoot length, where mean of this index for all levels of corm and leaf residue was 5.32 and $10.67 \mathrm{~cm}$, respectively. Considering the germination percentage, saffron leaf residue until $6 \%$ and corm residue up to $1.5 \%$ were the most appropriate concentrations for chickpea growth without any considerable deterrent allelopathic effect (Table 2). In similar study the results of Eghbali et al. (2008) showed that with increasing the amounts of saffron leaf residue added to the soil, the values of chlorophyll content, plant height, leaf area, shoot and root biomass of wheat, rye, vetch and bean increased, while with increasing the amount of saffron corm residue, all mentioned traits of the crops decreased compared with control treatment. Also, results of Yasmin et al. (1999) revealed that chickpea aqueous extract had an inhibitory effect on all germination and seedling growth indices of wheat, while, there was no negative effect of wheat on chickpea growth. Inhibiting effect of allelochemicals on germination and seedling growth is due to the alterations in some primary mechanisms such as cell ultra-structures, molecular biology as well as biochemical and physiological properties (Tanveer et al., 2012). Moreover, allelochemicals can alter the ions absorption rate and reduce macro and micronutrients concentrations in the plants (El-Darier \& El-Dien, 2011). In our study there was no considerable inhibiting effect of saffron residue on chickpea growth, however, understanding the mechanisms of inhibiting effects require to more biochemical and physiological studies with higher concentrations of saffron residue.

The life cycle of planted companion crops in saffron field must be as much as possible similar to saffron growth cycle, in terms of time, because irrigation is harmful to saffron after its leaf senescence stage in midMay (Koocheki et al., 2009). Chickpea is a cool season grain legume which reaches maturity stage approximately one month after saffron leaves senescence (Valimohammadi et al., 2007; Sharafzadeh, 2011). This plant is usually grown without irrigation and survives until harvesting despite progressively increasing drought (Krouma, 2010). Therefore, it could be an appropriate choice to be intercropped with saffron. This conclusion is due to the possible autumnal planting of chickpea, considerable synchronization of chickpea growth cycle with saffron and good resistance of chickpea against drought which is according to low water requirement of saffron.

\subsection{Effect of saffron residue on fenugreek early growth}

All measured seedling growth characters except for root dry mass were affected significantly by saffron residue 
(Table 3). Percentage of emergence increased up to the middle levels of leaf residue $(1.5 \%)$ and then decreased, so that, the amount of this index at the highest level of leaf residue (6\% leaf crude powder) was $17 \%$ lower than control treatment (Table 4). Emergence percentage was similar to control treatment up to the high levels of soil application of corm residue but then decreased about $12 \%$ in the highest level $(6 \%)$ of corm residue compared with the control treatment. The average value of this index for leaf residue levels was $81.5 \%$ and for all corm residue concentrations was $83.3 \%$ (Table 4). Emergence rate of fenugreek showed some reduction by increasing in concentration of saffron leaf residue and the value of this criterion at $6 \%$ leaf concentration decreased about $22 \%$ compared with the control treatment. Similarly, the amount of this index decreased significantly with increase in corm residue concentrations above $3 \%$, so that the value of this index in the highest level of corm residue application was $35 \%$ lower than control treatment (Table 4).

Root length of fenugreek seedlings decreased by soil application of saffron corm and leaf residue. In addition, there was no significant difference between control and leaf and corm residue levels in terms of shoot length. Root to shoot length ratio decreased in response to saffron leaf and corm residue application (Table 4). It seems that this phenomenon is because of roots are directly exposed to possible allelopathic compounds which can more affect their growth. This finding is similar to results of Eghbali et al. (2008) on wheat and bean but different with those obtained on rye and vetch. They reported that this variation is due to the differences in plant genetic nature. In addition, they stated that reduction in root to shoot ratio will probably lead to more plant sensitivity to environmental stress at later growth phases.

Table 3: Mean of square for the effects of experimental treatments (different concentrations of saffron corm and leaf residue) on emergence and seedling growth characters of fenugreek

\begin{tabular}{lccccccccc}
\hline $\begin{array}{l}\text { Sources of } \\
\text { variation }\end{array}$ & df & $\begin{array}{c}\text { Emergence } \\
\text { percentage }\end{array}$ & $\begin{array}{c}\text { Emergence } \\
\text { rate }\end{array}$ & $\begin{array}{c}\text { Root } \\
\text { length }\end{array}$ & $\begin{array}{c}\text { Shoot } \\
\text { length }\end{array}$ & $\begin{array}{c}\text { Root to } \\
\text { shoot } \\
\text { length } \\
\text { ratio }\end{array}$ & $\begin{array}{c}\text { Root } \\
\text { dry } \\
\text { mass }\end{array}$ & $\begin{array}{c}\text { Shoot dry } \\
\text { mass }\end{array}$ & $\begin{array}{c}\text { Root to } \\
\text { shoot } \\
\text { mass } \\
\text { ratio }\end{array}$ \\
\hline Treatment & 8 & $155.3^{*}$ & $1.60^{* *}$ & $4.26^{* *}$ & $0.60^{*}$ & $0.112^{* *}$ & $2.65^{\text {ns }}$ & $0.0000009^{\text {ns }}$ & $26.01^{\text {ns }}$ \\
Error & 18 & 51.0 & 0.25 & 0.85 & 0.37 & 0.016 & 2.28 & 0.0000006 & 0.65 \\
\hline C.V & - & 8.61 & 13.10 & 13.21 & 8.98 & 12.28 & 13.23 & 13.43 & 8.96 \\
\hline
\end{tabular}

**, * and ns, significant in $1 \%$ and $5 \%$ levels and not significant, respectively.

df and $\mathrm{CV}$ are degree of freedom and coefficient of variation, respectively. 
Table 4: Mean comparison of the effects of different levels of saffron corm and leaf residues on emergence and seedling growth criteria of fenugreek

\begin{tabular}{lcccccccc}
\hline $\begin{array}{c}\text { Treatment } \\
\text { (percentage } \\
\text { of residue) }\end{array}$ & $\begin{array}{c}\text { Emergence } \\
\text { percentage }\end{array}$ & $\begin{array}{c}\text { Emergence } \\
\text { rate } \\
\text { (seeding } \\
\text { per day) }\end{array}$ & $\begin{array}{c}\text { Root } \\
\text { length } \\
(\mathrm{cm})\end{array}$ & $\begin{array}{c}\text { Shoot } \\
\text { length } \\
(\mathrm{cm})\end{array}$ & $\begin{array}{c}\text { Root to } \\
\text { shoot } \\
\text { length } \\
\text { ratio }\end{array}$ & $\begin{array}{c}\text { Root dry } \\
\text { mass (g) }\end{array}$ & $\begin{array}{c}\text { Shoot dry } \\
\text { mass (g) }\end{array}$ & $\begin{array}{c}\text { Root to } \\
\text { shootmass } \\
\text { ratio }\end{array}$ \\
\hline Control & $87.0^{\mathrm{ab}}$ & $4.21^{\mathrm{bc}}$ & $9.56^{\mathrm{a}}$ & $6.63^{\mathrm{ab}}$ & $1.45^{\mathrm{a}}$ & $0.0019^{\mathrm{a}}$ & $0.0059^{\mathrm{a}}$ & $0.32^{\mathrm{a}}$ \\
$\mathrm{L}^{*} 0.5 \%$ & $88.6^{\mathrm{a}}$ & $4.13^{\mathrm{bc}}$ & $6.10^{\mathrm{c}}$ & $6.56^{\mathrm{ab}}$ & $0.93^{\mathrm{bc}}$ & $0.0019^{\mathrm{a}}$ & $0.0056^{\mathrm{a}}$ & $0.34^{\mathrm{a}}$ \\
$\mathrm{L} 1.5 \%$ & $90.3^{\mathrm{a}}$ & $4.10^{\mathrm{bc}}$ & $7.26^{\mathrm{bc}}$ & $6.66^{\mathrm{ab}}$ & $1.08^{\mathrm{b}}$ & $0.0025^{\mathrm{a}}$ & $0.0062^{\mathrm{a}}$ & $0.39^{\mathrm{a}}$ \\
$\mathrm{L} 3.0 \%$ & $77.33^{\mathrm{abc}}$ & $3.56 \mathrm{~b}^{\mathrm{cd}}$ & $6.66^{\mathrm{bc}}$ & $6.63^{\mathrm{ab}}$ & $1.00^{\mathrm{b}}$ & $0.0024^{\mathrm{a}}$ & $0.0061^{\mathrm{a}}$ & $0.41^{\mathrm{a}}$ \\
$\mathrm{L} 6.0 \%$ & $69.6^{\mathrm{c}}$ & $3.27^{\mathrm{cd}}$ & $6.16^{\mathrm{bc}}$ & $6.00^{\mathrm{b}}$ & $1.03^{\mathrm{b}}$ & $0.0017^{\mathrm{a}}$ & $0.0058^{\mathrm{a}}$ & $0.30^{\mathrm{a}}$ \\
$\mathrm{C} 0.5 \%$ & $87.3^{\mathrm{ab}}$ & $5.19^{\mathrm{a}}$ & $7.40^{\mathrm{bc}}$ & $6.76^{\mathrm{ab}}$ & $1.10^{\mathrm{b}}$ & $0.0017^{\mathrm{a}}$ & $0.0051^{\mathrm{a}}$ & $0.33^{\mathrm{a}}$ \\
$\mathrm{C} 1.5 \%$ & $85.6^{\mathrm{ab}}$ & $4.26^{\mathrm{b}}$ & $7.90^{\mathrm{b}}$ & $7.20^{\mathrm{a}}$ & $1.11^{\mathrm{b}}$ & $0.0021^{\mathrm{a}}$ & $0.0070^{\mathrm{a}}$ & $0.30^{\mathrm{a}}$ \\
$\mathrm{C} 3.0 \%$ & $85.6^{\mathrm{ab}}$ & $3.26^{\mathrm{cd}}$ & $6.33^{\mathrm{bc}}$ & $7.16^{\mathrm{ab}}$ & $0.88^{\mathrm{bc}}$ & $0.0022^{\mathrm{a}}$ & $0.0056^{\mathrm{a}}$ & $0.39^{\mathrm{a}}$ \\
$\mathrm{C} 6.0 \%$ & $74.6^{\mathrm{c}}$ & $2.71^{\mathrm{d}}$ & $5.70^{\mathrm{c}}$ & $7.53^{\mathrm{a}}$ & $0.75^{\mathrm{c}}$ & $0.0018^{\mathrm{a}}$ & $0.0056^{\mathrm{a}}$ & $0.32^{\mathrm{a}}$
\end{tabular}

$* \mathrm{~L}=$ leaf residue and $\mathrm{C}=$ corm residue. Means with the same letters in each column are not significantly different at the 0.05 level of probability.

Overall regards to emergence percentage and rate, 1.5 and $3 \%$ concentrations of saffron leaf and corm residue were the most appropriate treatment for fenugreek growth, but higher increase in residue resulted to occurrence of deterrent allelopathic effect (Table 4). In similar study it has been reported that the allelopathic effects of saffron corm residue on the early growth characters of wheat, rye, vetch and bean was inhibiting, while the allelopathic effect of saffron leaves residue was stimulating (Eghbali et al., 2008). Edrisi \& Farahbakhsh (2011) also reported that application of different concentrations of leaf extract of flixweed (Descurainia sophia (L.) Webb ex Prantl) exerted a positive effect on common wheat primary growth only up to the concentration of $4 \%$. In addition, results of Yasmin et al. (1999) showed that chickpea and wheat extracts are containing some compounds which had inhibitory or stimulatory effect on each other.

Our results showed that fenugreek root was relatively more sensitive to saffron corm and leaf powder than shoot. This result is in agreement with earlier study of Teerarak et al. (2010) and can be explained by this reason that roots are the first organ which emerge and are in direct contact with allelochemicals (Teerarak et al., 2010; Tanveer et al., 2012). Results of Eghbali et al. (2008) showed that soil application of saffron corm residue had more increasing effect on root biomass of rye and vetch, while its effect on wheat and bean was more effective on aerial part, because of differences in site and mode of action of allelochemicals in different crops.
Fenugreek is a vegetable, spice, medicinal, food and feed crop that can be a useful legume crop for incorporation into short-term rotation (Mehrafarin et al., 2011a). This nitrogen fixing crop is fairly drought resistant and generally grown as a winter crop in areas with mild winter and as spring crop in areas with soil that keeps moisture in the summer. The plant is partially a short living annual crop that its growth period is between 80 to 140 days, depend on ecotype, so that for spring and autumnal sowing, ripening take place usually 3-5 and about 7 months after sowing, respectively (Mehrafarin et al., 2011a). Therefore, considering the mentioned characteristics and the large coincidence of its growth cycle with saffron growth season, it could be used as a suitable associated crop in saffron cultivation especially as a green manure.

\subsection{Effect of saffron residue on arugula early growth}

Results of analysis of variance revealed that the effect of soil application of different levels of saffron leaf and corm residue was significant on all early growth indices of arugula (Table 5). Increase in concentration of saffron leaf residue caused a reduction in emergence percentage and rate, so that the amounts of these criteria in the highest leaf residue concentration decreased about 13 and $19 \%$ compared with the control treatment, respectively. However, the negative effects of corm residue on arugula emergence was observed at the lower concentrations of corm, but more increase in corm residue imposed a positive effect, where the highest 
emergence percentage among all experimental treatments was obtained at corm concentration of $6 \%$ (Table 6).

There were no significant differences in the mean root length with increase in the concentration of saffron leaf residue. However, saffron corm residue up to the concentration of $3 \%$ had a stimulatory effect on root length, but the higher concentrations of corm residue decreased the root growth. The positive effects of corm residue on root growth of arugula shows the lack of inhibiting compounds or even the nutritional values of saffron residue for its better growth (Eghbali et al. 2008). Root to shoot length ratio also was dosedependent, where leaf residue up to the concentration of $1.5 \%$ and corm residue up to the concentration of $3 \%$, increased the amount of this index. In addition, root mass of arugula showed a positive response to application of saffron leaf and corm residue. Its highest value obtained in the highest level of leaf residue, which was $42 \%$ more than control treatment. By increase in leaf residue concentration the shoot dry mass of arugula increased, while corm residue at concentrations above $1.5 \%$ had a deterrent effect on shoot mass (Table 6). Totally, the effect of saffron corm and leaf residue even until $6 \%$ concentration wasn't so inhibiting on early growth of arugula, therefore, this plant can be a good choice for intercropping with saffron.

In similar work, it has been reported that the aqueous extract of saffron petals had a positive effect on early growth indices of cotton (Gossypium hirsutum L.) in low and medium concentrations, whereas in high concentrations it decreased all measured indices (Eskandari- Torbaghan et al., 2007). A number of plant species have chemicals that cause allelopathic activity on the growth of other plants and under certain conditions, these compounds are released into the environment from living plants or residues in sufficient quantities to affect neighboring or successional plants (Kato-Noguchi et al., 2010). It has been reported that some allelochemicals reduce shoot and root expansion and plant growth by blocking of nutrient reserve, altering cell division and differentiation as well as prevention from ion and water uptake, phytohormon metabolism, respiration, photosynthesis, enzyme function, signal transduction and gene expression (ElDarier \& El-Dien, 2011).

Mixed cropping is one of the methods for increasing resource use efficiency in saffron cultivation. This strategy is only possible if there are no negative allelopathic interactions between the intercropped crops (Eskandari- Torbaghan et al., 2007). In a study it has been reported that saffron leaf and corm residue exerted different effects on growth criteria of bean and vetch, as its leaf tissue increased and corm tissue decreased seedling growth indices of the plants in compared with control (Eskandari- Torbaghan et al., 2007). Arugula is a fast growing, cool season crop with a short growth cycle (Jakše et al., 2013). It is an important oilseed crop of the rapeseed-mustard group that grown on marginal lands with poor fertility. Moreover, due to its drought tolerance and adaptability to adverse environmental conditions, it is preferred over Brassica species under water scarce conditions (Jakhar et al., 2010). Therefore, considering the mentioned characteristics combined with current experimental results it seems that arugula is a good choice to be intercropped with saffron.

Table 5: Mean of square for the effects of experimental treatments (different concentrations of saffron corm and leaf residue) on emergence and seedling growth characters of arugula

\begin{tabular}{|c|c|c|c|c|c|c|c|c|c|}
\hline $\begin{array}{l}\text { Sources } \\
\text { of } \\
\text { variation }\end{array}$ & $\mathrm{df}$ & $\begin{array}{l}\text { Emergence } \\
\text { percentage }\end{array}$ & $\begin{array}{c}\text { Emergence } \\
\text { rate }\end{array}$ & $\begin{array}{l}\text { Root } \\
\text { length }\end{array}$ & $\begin{array}{l}\text { Shoot } \\
\text { length }\end{array}$ & $\begin{array}{c}\text { Root to } \\
\text { shoot } \\
\text { length } \\
\text { ratio }\end{array}$ & $\begin{array}{l}\text { Root dry } \\
\text { mass }\end{array}$ & $\begin{array}{c}\text { Shoot } \\
\text { dry mass }\end{array}$ & $\begin{array}{c}\text { Root to } \\
\text { shoot } \\
\text { mass } \\
\text { ratio }\end{array}$ \\
\hline Treatment & 8 & $167.8^{* *}$ & $1.70^{* *}$ & $2.05^{* *}$ & $0.283^{*}$ & $0.215^{*}$ & $1.46^{*}$ & $1.20^{*}$ & $0.47^{*}$ \\
\hline Error & 18 & 23.8 & 0.44 & 0.25 & 0.167 & 0.100 & 9.85 & 8.05 & 0.16 \\
\hline C.V & - & 6.56 & 10.69 & 9.53 & 11.19 & 12.56 & 16.84 & 15.30 & 11.18 \\
\hline
\end{tabular}


Effect of different concentrations of saffron ... of arugula, chickpea and fenugreek under greenhouse conditions

Table 6: Mean comparison of the effects of different levels of saffron corm and leaf residue on emergence and seedling growth characters of arugula

\begin{tabular}{lcccccccc}
\hline $\begin{array}{c}\text { Treatment } \\
\text { (percentage } \\
\text { of residue) }\end{array}$ & $\begin{array}{c}\text { Emergence } \\
\text { percentage }\end{array}$ & $\begin{array}{c}\text { Emergence } \\
\text { rate } \\
\text { (seedling } \\
\text { per day) }\end{array}$ & $\begin{array}{c}\text { Root } \\
\text { ength } \\
(\mathrm{cm})\end{array}$ & $\begin{array}{c}\text { Shoot } \\
\text { length } \\
(\mathrm{cm})\end{array}$ & $\begin{array}{c}\text { Root to } \\
\text { shoot } \\
\text { length } \\
\text { ratio }\end{array}$ & $\begin{array}{c}\text { Root dry } \\
\text { mass (g) }\end{array}$ & $\begin{array}{c}\text { Shoot } \\
\text { dry mass } \\
(\mathrm{g})\end{array}$ & $\begin{array}{c}\text { Root to } \\
\text { shoot } \\
\text { mass } \\
\text { ratio }\end{array}$ \\
\hline Control $(0.0$ & $83.0^{\mathrm{a}}$ & $7.66^{\mathrm{a}}$ & $5.56^{\mathrm{bc}}$ & $4.00^{\mathrm{a}}$ & $1.39^{\mathrm{abc}}$ & $0.0008^{\mathrm{b}}$ & $0.0013^{\mathrm{b}}$ & $0.58^{\mathrm{b}}$ \\
$\mathrm{L}^{*} 0.5 \%$ & $84.0^{\mathrm{a}}$ & $6.90^{\mathrm{ab}}$ & $5.10^{\mathrm{bc}}$ & $3.66^{\mathrm{ab}}$ & $1.41^{\mathrm{abc}}$ & $0.0011^{\mathrm{ab}}$ & $0.0015^{\mathrm{ab}}$ & $0.73^{\mathrm{b}}$ \\
$\mathrm{L} 1.5 \%$ & $73.6^{\mathrm{b}}$ & $5.53^{\mathrm{c}}$ & $5.63^{\mathrm{bc}}$ & $3.20^{\mathrm{b}}$ & $1.79^{\mathrm{a}}$ & $0.0010^{\mathrm{ab}}$ & $0.0015^{\mathrm{ab}}$ & $0.68^{\mathrm{b}}$ \\
$\mathrm{L} 3.0 \%$ & $64.0^{\mathrm{c}}$ & $5.66^{\mathrm{bc}}$ & $5.00^{\mathrm{cd}}$ & $3.63^{\mathrm{ab}}$ & $1.37^{\mathrm{abc}}$ & $0.0014^{\mathrm{a}}$ & $0.0016^{\mathrm{ab}}$ & $0.91^{\mathrm{b}}$ \\
$\mathrm{L} 6.0 \%$ & $73.3^{\mathrm{b}}$ & $6.60^{\mathrm{abc}}$ & $5.43^{\mathrm{bc}}$ & $3.46^{\mathrm{ab}}$ & $1.03^{\mathrm{c}}$ & $0.0014^{\mathrm{a}}$ & $0.0019^{\mathrm{a}}$ & $0.76^{\mathrm{b}}$ \\
$\mathrm{C} 0.5 \%$ & $64.6^{\mathrm{bc}}$ & $5.56^{\mathrm{c}}$ & $4.13^{\mathrm{d}}$ & $3.96^{\mathrm{ab}}$ & $1.05^{\mathrm{bc}}$ & $0.0011^{\mathrm{ab}}$ & $0.0007^{\mathrm{c}}$ & $1.75^{\mathrm{a}}$ \\
$\mathrm{C} 1.5 \%$ & $71.6^{\mathrm{bc}}$ & $5.46^{\mathrm{c}}$ & $6.01^{\mathrm{ab}}$ & $3.60^{\mathrm{ab}}$ & $1.68^{\mathrm{a}}$ & $0.0012^{\mathrm{ab}}$ & $0.0016^{\mathrm{ab}}$ & $0.83^{\mathrm{b}}$ \\
$\mathrm{C} 3.0 \%$ & $73.3^{\mathrm{b}}$ & $6.46^{\mathrm{abc}}$ & $6.66^{\mathrm{a}}$ & $4.05^{\mathrm{a}}$ & $1.66^{\mathrm{ab}}$ & $0.0011^{\mathrm{ab}}$ & $0.0009^{\mathrm{c}}$ & $1.38^{\mathrm{ab}}$ \\
$\mathrm{C} 6.0 \%$ & $85.6^{\mathrm{ab}}$ & $6.13^{\mathrm{bc}}$ & $4.10^{\mathrm{d}}$ & $3.28^{\mathrm{ab}}$ & $1.25^{\mathrm{abc}}$ & $0.0009^{\mathrm{ab}}$ & $0.0007^{\mathrm{c}}$ & $1.33^{\mathrm{ab}}$ \\
\hline
\end{tabular}

$* \mathrm{~L}=$ leaf residue and $\mathrm{C}=$ corm residue. Means with the same letters in each column are not significantly different at the 0.05 level of probability.

\section{CONCLUSIONS}

This research was a preliminary greenhouse study towards possibility of simultaneous saffron and some associated crop cultivation (fenugreek, chickpea and arugula). Generally, the saffron corm and leaf residue not only did not considerably decrease the growth of tested crops, which in some cases increased their growth parameters. Therefore, these crops are potentially good candidates to be used in intercropping systems with saffron. However, it is also a need to be investigated the effects of proposed crops residue on saffron growth. Moreover, further studies under field conditions are necessary to evaluate the possible use of mentioned associated crops in saffron field.

\section{ACKNOWLEDGMENT}

This article is the result of a student project (in Sarayan Faculty of Agriculture), which financially supported by the Vice President for Research and Technology, University of Birjand, Iran.

\section{REFERENCES}

Abbassi, F. \& Jahani, M. (2007). Allelopathic effects of saffron corms on seed germination of several important crops. Acta Horticulture, 739, 269-273. https://doi.org/10.17660/ActaHortic.2007.739.33

Behdani, M.A., Fallahi, H.R. 2015. Saffron: Technical Knowledge Based on Research Approaches. University of Birjand Press. [In Persian].

Chengxu, C., Mingxing, Z., Xuhui, C. \& Bo, Q. (2011). Review on allelopathy of exotic invasive plants. Procedia Engineering, 18, 240-246. https://doi.org/10.1016/j.proeng.2011.11.038
Chon, C. U. \& Nelson, C. J. (2010). Allelopathy in compositae plants. A review. Agronomy for Sustainable Development, 30, 349-358. https://doi.org/10.1051/agro/2009027

Edrisi, S. \& Farahbakhsh, A. (2011). Allelopathic Effects of Sisymbrium irio L. and Descurainia sophia (L.) Schur on the Germination of Wheat (Triticum aestivum L.). World Academy of Science, Engineering and Technology, 50, 638-640.

Eghbali, S., Rashed Mohassel, M. H., Nassiri Mahallati, M. \& Kazerooni Monfared, E. (2008). Allelopathic potential of shoot and corm of saffron residues on 
wheat, rye, vetch and bean. Journal of Field Crops Researches, 6(2), 227-234.( In Persian with English Summary).

El-Darier, S. M. \& El-Dien, M. H. Z. (2011). Biological activity of Medicago sativa L. (alfalfa) residues on germination efficiency, growth and nutrient uptake of Lycopersicon esculentum L. (tomato) seedlings. Journal of Taibah University for Science, 5, 7-13. https://doi.org/10.1016/S1658-3655(12)60033-8

Eskandari-Torbaghan, M., Abbasi, R. \& Astaraei, A. (2007). Effect of saffron (Crocus sativus L.) petals on germination and primary growth of cotton (Gossypium hirsutum L.). Acta Horticulture, 739, 87-91. https://doi.org/10.17660/ActaHortic.2007.739.10

Fallahi, H. R., Paravar, A., Behdani, M. A., AghhavaniShajari, M. \& Fallahi, M. J. (2014). Effects of Saffron corm and leaf extracts on early growth of some plants to investigate the possibility of using them as associated crop. Notulae Scientia Biologicae, 6(3), 282-287. https://doi.org/10.15835/nsb.6.3.9259

Fallahi, H. R., Fadaeian, G., Gholami, M., Daneshkhah, O., Hosseini, F.S., Aghhavani-Shajari, M. \& Samadzadeh, A. (2015). Germination response of grass pea (Lathyrus sativus L.) and arugula (Eruca sativa L.) to osmotic and salinity stresses. Plant Breeding and Seed Science, 71, 97-108. https://doi.org/10.1515/plass-2015-0025

Faravani, M., Behshtii, A. \& Khanizadeh, H. (2010). Yield performance of black zira and saffron intercropping system in different plant distances and replacement series. International Journal of Science and Nature, 1(2), 195-197.

Farooq, M., Bajwa, A. A., Cheema, S., Cheema, Z. A. (2013). Application of allelopathy in crop production. International Journal of Agriculture and Biology, 15, 1367-1378.

Ganjeali, A., Parsa, M. \& Amiri-Deh-Ahmadi, S.R. (2011). Determination of cardinal temperatures and thermal time requirement during germination and emergence of chickpea genotypes (Cicer arietinum L.). Iranian Journal of Pulses Research, 2(2), 97108. In Persian with English Summary).

Jakhar, M. L., Jajoria, R. N., Sharma, K. C., \& Ram, S. (2010). Genetic divergence in Taramira (Eruca sativa Mill.). Journal of Oilseed Brassica, 1(2), 7983.

Jakše, M., Hacin, J. \& Kacjan Maršić, N. (2013). Production of rocket (Eruca sativa Mill.) on plug trays and on a floating system in relation to reduced nitrate content. Acta Agriculturae Slovenica,
101(1), 59- 68. https://doi.org/10.2478/acas-20130007

Jalilian, J. \& Khalili-Aqdam, N. (2014). Effects of alternative temperatures on germination rate of rocket seed (Eruca sativa). Iranian Journal of Seed Research, 2(1), 127-133. In Persian with English Summary).

Kato-Noguchi, H., Seki, T. \& Shigemori, H. (2010). Allelopathy and allelopathic substance in the moss Rhynchostegium pallidifolium. Journal of Plant Physiology, 167, 468-471. https://doi.org/10.1016/j.jplph.2009.10.018

Khosravi, M. (2005). Intercropping black zira (Bonium persicum) with saffron and annual crops: Agroecological and economic perspectives. $\mathrm{PhD}$ Thesis, Faculty of Agriculture, Ferdowsi University of Mashhad, Iran. (In Persian with English Summary).

Koocheki, A., Najibnia, S. \& Lalehgani, B. (2009). Evaluation of saffron yield (Crocus sativus L.) in intercropping with cereals, pulses and medicinal plants. Iranian Journal of Field Crops Research, 7(1), 163-172. (In Persian with English Summary).

Koocheki, A., Rezvani Moghaddam, P. \& Fallahi, H. R., (2016). Effects of planting dates, irrigation management and cover crops on growth and yield of saffron (Crocus sativa L.). Journal of Agroecology, 8(1), 435-451. (In Persian with English Summary).

Krouma, A. (2010). Plant water relations and photosynthetic activity in three Tunisian chickpea (Cicer arietinum L.) genotypes subjected to drought. Turkish Journal of Agriculture and Forestry, 34, 257-264.

Kumar, R., Virendra, S., Kiran, D., Sharma, M., Singh, M. K. \& Ahuja, P. S. (2009). State of art of saffron (Crocus sativus L.) agronomy: A comprehensive review. Food Reviews International, 25, 44-85. https://doi.org/10.1080/87559120802458503

Maguire, J. D. (1962). Speed of germination aid in selection and evaluation for seedling emergence and vigor. Crop Science, 2, 176-177. https://doi.org/10.2135/cropsci1962.0011183X0002 00020033x

Marsaglia, G., Tsang, W.W. \& Wang, J. (2003). Evaluating Kolmogorov's distribution. Journal of Statistical Software, $\quad 8(18), \quad$ 1-4. https://doi.org/10.18637/jss.v008.i18

Mehrafarin, A., Rezazadeh, S., Naghdi Badi, H., Noormohammadi, G., Zand, E. \& Qaderi, A. (2011a). A review on biology, cultivation and biotechnology of Fenugreek (Trigonella foenum- 
graecum L.) as a valuable medicinal plant and multipurpose. Journal of Medicinal Plants, 37, 624.

Mehrafarin, A., Naghdi Badi, H., Noormohammadi, G., Zand, E., Rezazadeh, S. \& Qaderi, A. (2011b). Effects of environmental factors and methanol on germination and emergence of Persian Fenugreek (Trigonella foenum-graecum L.). African Journal of Agricultural Research, 6(19), 4631-4641.

Mohammad-Abadi, A. A., Rezvani-Moghaddam, P. \& Fallahi, H. R. (2011). Effects of planting pattern and the first irrigation date on growth and yield of saffron. Journal of Agroecology, 3(1), 84-93. (In Persian with English Summary).

Molina, R. V., Valero, M., Navarro, Y., Guardiola, J. L. \& Garcia-Luis, A. (2005). Temperature effects on flower formation in saffron (Crocus sativus L.). Scientia Horticulturae, 103, 361-379. https://doi.org/10.1016/j.scienta.2004.06.005

Naderi Darbaghshahi, M. R., Banitab, A. R. \& Bahari, B. (2012). Evaluating the possibility of saffron and chamomile mixed culture. African Journal of Agricultural Research, 7(20), 3060-3065. https://doi.org/10.5897/AJAR11.999

Rashed Mohassel, M. H., Gherekhloo, J. \& Rastgoo, M. (2009). Allelopathic effects of saffron (Crocus sativus) leaves and corms on seedling growth of redroot pigweed (Amaranthus retroflexus) and lambsquarter (Chenopodium album). Iranian Journal of Field Crop Research, 7(1), 53-61.
Sharafzadeh, S. (2011). Saffron: A concise review of researches Advances in Environmental Biology, 5(7), 1617-1621.

Tanveer, A., Jabbar, M. K., Kahliq, A., Matloob, A., Abbas, R. N. \& Javaid, M. M. (2012). Allelopathic effects of aqueous organic fractions of Euphorbia dracunculoides Lam on germination and seedling growth of chickpea and wheat. Chilean Journal of Agricultural Research, 72(4), 495-501. https://doi.org/10.4067/S0718-58392012000400006

Teerarak, M., Laosinwattana, C. \& Charoenying, P. (2010). Evaluation of allelopathic, decomposition and cytogenetic activities of Jasminum officinale L. f. var. grandiflorum (L.) Kob. on bioassay plants. Bioresource Technology, 101, 5677-5684. https://doi.org/10.1016/j.biortech.2010.02.038

Valimohammadi, F., Tajbakhsh, M. \& Saied, A. (2007). Comparison winter and spring sowing dates and effect of plant density on yield, yield components and some quality, moephological traits of chickpea (Cicer arietinum L.) under environmental condition of Urmia, Iran. Journal of Agronomy, 6(4), 571575. https://doi.org/10.3923/ja.2007.571.575

Yasmin, S., Saleem, B. \& Irshad, A. (1999). Allelopathic effects of aqueous extract of chickpea (Cicer arietinum) and wheat (Triticum aestivum L.) on each other's growth and quality. International Journal of Agriculture and Biology, 3, 110-111. 